Vol. : : 1 (2), 2019, 155-176

P-ISSN : 2686-1607

E-ISSN : 2686-4819

\title{
PENERAPAN 'URF SEBAGAI METODE DAN SUMBER HUKUM EKONOMI ISLAM
}

\author{
Fitra Rizal \\ Institut Agama Islam Sunan Giri Ponorogo \\ email: fitrajal@gmail.com
}

\begin{abstract}
The development of an increasingly advanced industry has an impact on the development of transactions in an increasingly complex economy so that many transaction activities that require ijtihad to find solutions to problems that may arise. The hope is that the transaction can run smoothly and in accordance with Islamic law. This study aims to discuss matters relating to how 'urf becomes the methods and sources of Islamic law in economic activities using a qualitative research methodology with a library research approach. The results showed that 'urf' is a thing that is known and has become a habit of the community, both in the form of words or deeds. So 'urf can be used as a method and legal basis for economic transaction activities. Some examples of the application of 'urf in Islamic economic transactions are buying and selling transactions in modern shopping centers and some online-based economic transactions without saying shighat (I sell-I buy). Although the practice of buying and selling is not like the shighat described in classical literature, but because it contains a meaning that indicates the willingness of both parties it can be concluded that the transaction law may be based on 'urf.
\end{abstract}

Keywords: Islamic Economics, 'Urf, Method, Legal Resources

Abstrak: Perkembangan industri yang semakin maju berdampak pada perkembangan transaksi dalam ekonomi yang semakin komplek sehingga banyak kegiatan transaksi yang membutuhkan ijtihad untuk mencari solusi dari permasalan yang mungkin muncul. Harapanya agar transaksi tersebut dapat berjalan lancar dan sesuai dengan syariat Islam. Penelitian ini bertujuan untuk membahas hal-hal yang berkaitan dengan bagaimana 
'urf menjadi metode dan sumber hukum Islam dalam kegiatan perekonomian dengan menggunakan metodologi penelitian kualitatif dengan pendekatan kepustakaan (library research). Hasil penelitian menunjukkan bahwa 'urf 'merupakan suatu hal yang dikenal dan sudah menjadi kebiasaan masyarkat, baik berupa ucapan ataupun perbuatan. Sehingga 'urf dapat dijadikan metode dan landasan hukum dalam kegiatan transaksi ekonomi. Beberapa contoh penerapan 'urf dalam transaksi ekonomi Islam dalah transaksi jual beli di pusat perbelanjaan modern dan beberapa transaksi ekonomi yang berbasis online tanpa mengucapkan shighat (saya jual-saya beli). Walaupun praktik jual beli yang dilakukan tidak seperti shighat yang dijelaskan di literature klasik, namun karena mengandung arti yang menunjukkan kerelaan dari kedua belah pihak maka dapat disimpulkan bahwa hukum transaksi tersebut boleh berdasarkan 'urf.

Kata Kunci: Ekonomi Islam, 'Urf, Metode, Sumber Hukum

\section{PENDAHULUAN}

Saat ini ekonomi Islam telah mengalami kemajuan yang pesat dan berkesinambungan. Kemajuan tersebut meliputi berbagai dimensi seperti kajian akademis di Perguruan Tinggi, maupun praktik operasional pada lembaga-lembaga perekonomian. Keadaan tersebut diharapkan terus berkembang dalam berbagai aspek, seperti kebijakan ekonomi seperti kebijakan fiskal, kebijakan moneter, dan permasalahan ekonomi lainnya, seperti halnya dalam produksi, konsumsi, distribusi, upah, sumberdaya manusia, sumberdaya alam, perindustrian, teknologi dan sebagainya. Dalam perkembangan tersebut, agar tetap mampu bersaing dan sesuai dengan kebutuhan masyarakat, diperlukan regulasi yang memadai, inovasi produk dan strategi pengembangan, inovasi strategi marketing, serta merespon secara akomodatif terhadap bentukbentuk baru transaksi ekonomi dengan tetap mematuhi prinsip-prinsip syariah dalam operasionalnya. 
Perlu diperhatiakan bahwa kompleksitas persoalan yang berkembang di tengah masyarakat harus dijawab secara logis serta sesuai syariah. Permasalahannya adalah tidak semua kasus baru tersebut telah dijelaskan dalam al-Qura'an maupun al-Hadis. Karena setiap kejadian dan peristiwa dalam masyarakat selalu berkembang, maka harus ada usaha untuk berijtihad dan beranalogi menggunakan kaidah-kaidah yang didasari atas sumber hukum Islam tesebut.

Kondisi di atas memicu para ulama membuat kaidah fiqh yang bisa dijadikan panduan dalam pengambilan hukum yang belum secara jelas tersurat dalam al-Qur'an dan al-Hadis. Hukum sangat penting untuk mengatur prilaku masyarakat agar teratur dan terarah sesuai syariah. Dapat dipastikan, seiiring perkembangan zaman maka dapat dipastikan perkembangan permasalahan yang dihadapi masyarakat juga akan berkembang begitu pula dalam bidang ekonomi. ${ }^{1}$ Apalagi saat ini dunia telah mengalami revolusi industri yang mengubah cara kerja manusia dari penggunaan manual menjadi otomatisasi atau digitalisasi.

Dalam kehidupan masyarakat banyak terdapat kebiasaankebiasaan atau tradisi yang populer secara luas di tengah kehidupan mereka. Tradisi tersebut dapat berupa perkataan atau perbuatan yang berlaku secara umum, hal semacam ini disebut dengan 'urf. Kebiasaankebiasaan tersebut dapat menjadi bahan pertimbangan ketika akan menetapkan hukum Islam dalam transaksi ekonomi yang semakin berkembang terutama terkait masalah-masalah yang tidak ada ketegasan hukum dalam al-Qur'an dan al-Hadit. ${ }^{2}$

Pembahasan adat kebiasaan sebagai 'urf di dalam usul al-fiqh ditekankan pada kedudukannya sebagi suatu kepantasan yang telah dikenal secara luas oleh masyarakat. Dan 'urf yang menjadi pertimbangan

1 Toha Andiko, Ilmu Qowa'id Fiqhiyyah Panduan Praktis dalam Memproses Problematika Hukum Islam Kontemporer (Yogyakarta: Teras, 2011), 139.

${ }^{2}$ Andiko. 
hukum Islam hanyalah'urf shahih saja. ${ }^{3}$ Berdasarkan latar belakang di atas, maka penelitian ini bertujuan untuk membahas hal-hal yang berkaitan dengan bagaimana 'urf menjadi metode dan sumber hukum Islam dalam kegiatan perekonomian. Oleh karena itu penelitian ini menggunakan metodologi penelitian kualitatif dengan menggunakan pendekatan kepustakaan (library research) deskriptif-interpretatif.

\section{'URF DALAM HUKUM ISLAM}

'Urf berasal dari kata 'arafa yang mempunyai derivasi kata alma'ruf yang berarti sesuatu yang dikenal atau diketahui. ${ }^{4}$ Sedangkan 'urf menurut bahasa adalah kebiasan yang baik. Adapun pengertian 'urf adalah sesuatu perbuatan atau perkataan dimana jiwa merasakan suatu ketenangan dalam mengerjakannya karena sudah sejalan dengan logika dan dapat diterima oleh watak kemanusiaannya. ${ }^{5}$ Menurut fuqaha, 'urf adalah segala sesuatu yang telah menjadi kebiasaan masyarakat dan dilakukan terus-menerus, baik berupa perkataan maupun perbuatan. ${ }^{6}$ Maka dapat dipahami, 'urf adalah perkataan atau perbuatan baik yang telah populer dan dikerjakan oleh orang banyak dalam masyarakat. Artinya 'urf merupakan kebiasaan baik yang dilakukan secara berulangulang oleh masyarakat. Dasar penggunaan 'urf adalah sebagai berikut, Allah berfirman dalam QS. Al-Araf 199.

3 Abdul Mun'im Saleh, Hubungan kerja Usul al-Fiqh dan al-Qawaid al-Fiqhiyah Sebagai Metode Hukum Islam (Yogyakarta: Nadi Pustaka, 2012), 43.

4 Rijal Mumazziq Zionis,"Posisi al-'Urf dalam Struktur Bangunan Hukum Islam”. Jurnal Falasifa, Vol. 2 No. 2, Sekolah Tinggi Agama Islam al-Falah As-Sunniyyah (STAIFAS), 2011), 132.

5 Muhammad ma'sum Zainy al-Hasyimy, Sistematika Teori Hukum Islam (Qowa'id Fiqhiyyah) (Jombang: Darul Hikmah Jombang dan Maktabah al-Syarifah AlKhodijah, 2008), 79-80.

6 Umar Syihab, Hukum Islam dan Trasformasi Pemikiran (Semarang: Dina Utama Semarang (Toha Putra Group), 1996), 30. 


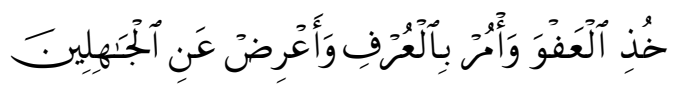

Artinya: Dan suruhlah orang mengerjakan yang ma'ruf dan berpalinglah dari orang-orang yang bodoh (al-'Araf: 199).

Ayat diatas menunjukkan dengan jelas bahwa Allah menyuruh supaya kita menggunakan 'urf. Kata 'urf dalam ayat diatas dimaknai dengan suatu perkara yang dinilai baik oleh masyarakat.7 Ayat tersebut dapat dipahami sebagai perintah untuk mengerjakan sesuatu yang telah dianggap baik sehingga menjadi tradisi dalam suatu masyarakat. seruan ini didasarkan pada pertimbangan kebiasaan yang baik dan dinilai berguna bagi kemaslahatan mereka.

Begitu juga dalam al-Hadis yang diriwayatkan oleh Ahmad dari Ibnu Masud bahwa Nabi Muhammad Saw bersabda yang artinya, "Segala sesuatu yang dipandang oleh (orang-orang Islam) umum itu baik, maka baik pulalah di sisi Allah dan segala sesuatu yang dipandang oleh (orangorang Islam) umum itu jelek, maka jelek pulalah di sisi Allah". 8

Secara ekplisit, hadith diatas menunjukkan bahwa persepsi positif komunitas muslim pada suatu persoalan, bisa dijadikan sebagai salah satu dasar bahwa hal tersebut juga bernilai positif disisi Allah. Dengan demikian hal tersebut tidak boleh ditentang atau dihapus, akan tetapi bisa dijadikan pijakan untuk mendisain produk hukum, karena pandangan umum itu hakikatnya tidak bertentangan dengan apa yang telah dikehendaki Allah. ${ }^{9}$ Pada dasarnya, 'urf tidak mempersulit kehidupan, tetapi sangat membantu dalam mengatur tata hidup

${ }^{7}$ Ahmad Sufyan Che Abdullah, "Aplikasi Doktrin al-'Urf dalam Istrumen Pasaran Kewangan Islam di Malaysia”. Skripsi (2002) 25.

8 Muhammad Ma'sum Zainy al-Hasyimy, Pengantar Memahami Nadhom alFaroidul Bahiyyah (Jombang: Darul Hikmah Jombang, 2010), 162.

9 Ibid. 
bermasyarakat dan juga mengatur kehidupan setiap anggota masyarakat tersebut. ${ }^{10}$

Imam al-Syatibi dan Ibn Qayyim al-Jauziyah, berpendapat bahwa 'urf bisa diterima sebagai dalil untuk menetapkan hukum Islam. Namun, kedua Imam tersebut memberikan catatan, apabila tidak ada nas\} yang menjelaskan hukum masalah tersebut. ${ }^{11}$ Dari-dalil diatas juga dapat dipahami, apabila terjadi suatu perselisihan pandangan dalam jual-beli, sewa-menyewa atau kerja sama antara pemilik sawah dan penggarapnya, dan lain sebagainya. Maka penyelesaiannya dapat disesuaikan dengan adat kebiasaan ('urf) yang telah berlaku di masyarakat tesebut. Dan jika adat tersebut bertentangan dengan nas\} seperti praktek ribawi dan kebiasaan suap-menyuap, maka hal tesebut tidak dibenarkan. Dalam konteks hukum Islam, para Ulama berpendapat bahwa hanya 'urf sahih sajalah yang dapat dijadikan sebagai landasan hukum. ${ }^{12}$

Suatu hukum yang ditetapkan atas dasar 'urf dapat berubah karena kumungkinan adanya perubahan 'urf itu sendiri atau perubahan tempat, zaman dan sebagainya. Sebagian mendasarkan hal itu pada kenyataan bahwa, Imam Syafi'i ketika di Irak mempunyai pendapatpendapat yang berlainan dengan pendapat beliau sendiri setelah pindah ke Mesir. Di kalangan Ulama, pendapat Imam Syafi'i ketika di Irak disebut dengan qawl qadim, segangkan pendapat di Mesir disebut qaw jaddid. Adapun alasan para Ulama yang memakai 'urf dalam menentukan hukum antara lain: Banyak hukum syariah yang ternyata sebelumnya telah menjadi kebiasaan orang Arab. Seperti adanya wali dalam

10 Mohd Anuar Ramli, "Instrumen 'urf dan Adat Melayu Sebagai Asas Penetapan Hukum Semasa di Malaysia”. Jurnal Pengajian Melayu, Jilid 17, (2006), 257.

11 Imron Rosyadi, "Kedudukan al-'Adah Wa Al-'urf dalam Bangunan Hukum Islam". Jurnal Suhuf Vol. Xvii, No. 01 (2005), 6.

12 Toha Andiko, Ilmu Qowa'id Fiqhiyyah Panduan Praktis dalam Memproses Problematika Hukum Islam Kontemporer , 146. 
pernikahan. Dan transaksi jual beli tanpa sighat (tanpa menyebutkan akadnya) yang sudah sangat umum terjadi. ${ }^{13}$

Sehingga kaidah pokok dalam 'urf adalah العَدَادَة مُحْكَمَّة yang artinya, Adat itu bisa dijadikan patokan hukum. Dan dalam kaidah lain dinyatakan

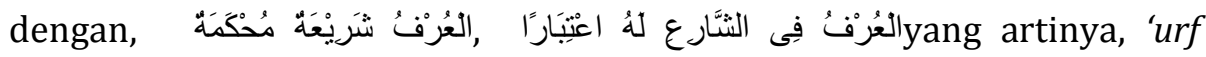
menurut shara' itu memiliki suatu penghargaan (bernilai hujjah) dan kaidah 'urf merupakan dasar hukum yang telah dikokohkan. ${ }^{14}$ Misalnya, kebiasaan seorang laki-laki yang melamar seorang wanita dengan memberikan sesuatu sebagai hadiah, bukan sebagai mahar. ${ }^{15}$

\section{MACAM-MACAM 'URF}

Bila ditinjau dari jenis pekerjaannya,'urf dibagi menjadi'urf qawli dan 'urf fi'li. Dan jika ditinjau dari aspek kuantitas pelakunya, 'urf terbilah menjadi 'urf 'am dan 'urf khas. ${ }^{16}$ 'Urf qawli adalah sejenis kata, ungkapan, atau istilah tertentu yang diberlakukan oleh sebuah komunitas untuk menunjuk makna khusus, dan tidak ada kecenderungan makna lain di luar apa yang mereka pahami. Artinya ketika kata itu diucapkan, maka yang terbesit dalam hati mereka adalah makna yang khusus tersebut, bukan antonim makna lainnya. Contohnya ketika orang Arab mengucapkan walad (anak), maka mereka pasti mengartikannya sebagai anak laki-laki, bukan anak perempuan.

Sementara 'urf fi'li adalah sejenis pekerjaan atau aktivitas tertentu yang sudah biasa dilakukan secara terus menerus, sehingga dipandang sebagai norma sosial. Dalam budaya masyarakat Arab, 'urf fi'li

13 Basiq Djalil, Ilmu Ushul Fiqh Satu dan Dua (Jakarta: Kencana Prenada Media Group, 2010), 162.

14 Muhammad Ma'sum Zainy al-Hasyimy, Sistematika Teori Hukum Islam (Qowa'id Fiqhiyyah) , 79.

15 Toha Andiko, Ilmu Qowa'id Fiqhiyyah Panduan Praktis dalam Memproses Problematika Hukum Islam Kontemporer, 147. Islam", 143.

16 Rijal Mumazziq Zionis, "Posisi al-'Urf dalam Struktur Bangunan Hukum 
dapat disaksikan pada transaksi jual beli tanpa sighat (tanpa menyebutkan akadnya) yang sudah sangat umum terjadi. Karena sudah menjadi hal yang lumrah di masyarakat dan sudah menjadi kebiasaan masyarakat yang sulit dihindari.

'Urf 'am adalah bentuk pekerjaan yang sudah berlaku menyeluruh dan tidak mengenal batas waktu, pergantian generasi, atau letak geografis. Tradisi jenis ini bersifat lintas batas, lintas cakupan, dan lintas zaman. Contohnya adalah memasak dengan kompor, penumpang angkutan umum yang bercampur antara laki-laki dan permpuan.

'Urf khas adalah sejenis kebiasaan yang berlaku di kawasan atau golongan tertentu, dan tidak tampak pada komunitas lainnya. 'urf yang bisa berubah dan berbeda karena perbedaan tempat dan waktu. Sehingga hanya berlaku dan dikenal disuatu tempat atau masyarakat tertentu. Contohnya adalah pedagang menetapkan piutangnya dengan menuliskannya dalam daftar khusus tanpa saksi, penggunaan kata "kendaraan" untuk himar disuatu negeri dan kuda dinegeri lainnya. ${ }^{17}$

Secara umum, hanya terdapat dua kategori 'urf, yaitu 'urf sahih dan 'urf fasid, dengan penjelasan sebagai berikut:18 'Urf sahih adalah segala sesuatu yang sudah dikenal umat manusia yang tidak berlawanan dengan dalil shara'. Dan ia tidak menghalalkan yang haram dan tidak menggugurkan kewajiban. Misalnya, kebiasaan seorang laki-laki yang melamar seorang wanita dengan memberikan sesuatu sebagai hadiah, bukan sebagai mahar. 'Urf fasid adalah 'urf yang jelek dan tidak bisa diterima karena bertentangan dengan shara'. Dari pendapat ini dapat diketahui bahwa setiap kebiasaan yang menghalalkan yang diharamkan

17 Sulaiman Abdullah, Sumber Hukum Islam Permasalahan dan Fleksibilitinya (Jakarta: Sinar Grafika, 2007),78.

18 Toha Andiko, Ilmu Qowa'id Fiqhiyyah Panduan Praktis dalam Memproses Problematika Hukum Islam Kontemporer , 147. 
Allah dan mengandung maksiat masuk dalam jenis ini. Misalnya, kebiasaan masyarakat mengkonsumsi minuman keras pada suatu pesta.

\section{SYARAT 'URF SEBAGAI LANDASAN HUKUM ISLAM}

Para Ulama sepakat bahwa tidak semua 'urf bisa dijadikan sebagai dalil untuk menetapkan hukum Islam.'urf dapat diterima sebagai salah satu landasan hukum jika memenuhi syarat-syarat sebagai

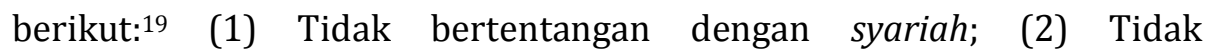
menyebabkan kemafsadahan dan tidak menghilangkan kemaslahatan; (3) Telah berlaku umum dikalangan kaum muslim; 4) Tidak berlaku dalam ibadah mahdhoh; (5) 'Urf tersebut sudah memasyarakat saat akan ditetapkan sebagai salah satu patokan hukum.

Sedangkan menurut al-Zarqa, 'urf baru dapat dijadikan sebagai salah satu dalil dalam menetapkan hukum Islam apabila memenuhi syarat sebagai berikut:20 (1) 'Urf tersebut harus berlaku secara umum. Artinya, adat itu berlaku dalam kebanyakan kasus yang terjadi dalam masyarakat dan keberlakuannya dianut oleh mayoritas masyarakat tersebut. (2) 'Urf yang akan dijadikan sebagai dalil hukum Islam adalah 'urf yang telah berjalan sejak lama di suatu masyarakat ketika pesoalan yang akan ditetapkan hukumnya itu muncul. Artinya, 'urf yang akan dijadikan sandaran hukum itu lebih dahulu ada sebelum kasus yang akan ditetapkan hukumnya. (3) 'Urf yang akan dijadikan sebagai dasar penetapan hukum tidak bertentangan dengan yang diungkapkan secara jelas oleh para pihak dalam masalah yang sedang dilakukan. Sebagai contoh, antara penjual dan pembeli ketika melakukan transaksi jual-beli telah menyepakati bahwa dengan kesepakatan secara jelas bahwa barang yang dibeli akan dibawa sendiri oleh pembeli ke rumahnya.

19 Muhammad Ma'sum Zainy al-Hasyimy, Sistematika Teori Hukum Islam (Qowa'id Fiqhiyyah) (Jombang, 83. Islam",7.

20 Imron Rosyadi, "Kedudukan al-'Adah wa al-'urf dalam Bangunan Hukum 
Padahal kebiasaan yang berlaku adalah barang yang dibeli akan diantarkan penjualnya ke rumah pembeli. Ini berarti bahwa ada pertentangan antara 'urf dan yang diungkapkan secara jelas dalam transaksi tersebut. Bila demikian keadaannya, maka'urf yang berlaku di masyarakat tidak bisa dijadikan sebagai dasar untuk menetapkan hukum dalam jual beli tersebut. (4) 'Urf dapat diterima sebagai dasar hukum Islam manakala tidak ada nas\} yang mengandung hukum dari permasalahan yang dihadapi. Artinya, bila suatu permasalahan sudah ada nashnya, maka adat itu tidak dapat dijadikan sebagai dalil hukum Islam.

\section{PANDANGAN ULAMA TERHADAP 'URF SEBAGAI DALIL HUKUM ISLAM}

Para Ulama membenarkan penggunaan 'urf hanya dalam hal-hal muamalah, itupun setelah memenuhi syarat-syarat di atas. Perlu diketahuai bahwa dalam hal ibadah secara mutlak tidak berlaku 'urf karena yang menentukan dalam hal ibadah adalah al-Qura'an dan alHadith. ${ }^{21}$ 'Urf bertujuan untuk memlihara kemaslahatan umat serta menunjang pembetulan hukum dan penafsiran beberapa nas. ${ }^{22}$

Berikut ini pandangan para Ulama terkait 'urf:23 (1) Abu Yusuf dari kelompok 'ulama Hanafi dan mayoritas 'ulama non Hanafiah berpendapat bahwa hukum shara' itu juga berubah mengikuti perkembangan adat kebiasaan atau 'urf yang bersangkutan. Hal ini sesua degan kaidah "tidak dapat diingkari perubahan hukum itu disebabkan oleh perubahan zaman dan tempat". (2) Abu Hanifah dan Muhammad bin

21 Basiq Djalil, Ilmu Ushul Fiqh Satu dan Dua (Jakarta: Kencana Prenada Media Group, 2010), 163.

22 Racmat Syafe'i, Ilmu Ushul Fiqh (Bandung: Pustaka Setia, 2010), 131.

23 Muhammad Ma'sum Zainy al-Hasyimy, Pengantar Memahami Nadhom alFaroidul Bahiyyah, 184. 
Hasan berpendapat bahwa yang tetap menjadi patokan hukum adalah 'urf yang lama pada saat datangnya nas\} yang bersangkutan. (3) Abdul Wahab Khalaf berpendapat bahwa pada dasarnya 'urf itu bukan dalil shara' yang berdiri sendiri, sebab ia termasuk memelihara maslahah mursalah. Maka jika 'urf dijadikan pertimbangan salah satu patokan hukum, maka dipertimbangkan pula dalam menafsirkan nash. Bahkan terkadang qiyas ditinggalkan lantaran 'urf dianggap lebih sesuai, misalnya sah hukum transaksi sengan sistem salam dan istisna', sekalipun menurut qiyas tidak sah karena barngnya belum atau tidak ada pada saat bertransaksi.

\section{PERBANDINGAN 'URF DENGAN 'ADAH}

Definisi 'urf menurut kamus bahasa Arab semakna dengan ma'ruf yaitu sesuatu yang diketahui manusia dari segala kebaikan dan mereka menerimanya degan tenang dan nyaman. Dalam bahasa Melayu, diterjemahkan dengan sesuatu yang dipahami sebagai adat. Sedangkan 'adah dalam kamus bahasa Arab dipahami dengan sesuatu yang berulang-ulang dan dalam bahasa Melayu disebut dengan kebiasaan. ${ }^{24}$

Dan pengertian yang lain, 'urf adalah sesuatu perbuatan atau perkataan dimana jiwa merasakan suatu ketenangan dalam mengerjakannya karena sudah sejalan dengan logika dan dapat diterima oleh watak kemanusiaannya. Sedangkan 'adah dapat didefinisikan dengan suatu perbuatan atau perkataan yang terus menerus dilakukan oleh manusia lantaran dapat diterima akal dan secara kontinyu manusia mahu mengulanginya. Berdasarkan definisi diatas dapat dipahami antara, 'urf dan 'adah memiliki arti yang sama. ${ }^{25}$

24 Toha Andiko, Ilmu Qowa'id Fiqhiyyah Panduan Praktis dalam Memproses Problematika Hukum Islam Kontemporer , 139.

25 Muhammad Ma'sum Zainy al-Hasyimy, Sistematika Teori Hukum Islam (Qowa'id Fiqhiyyah) , 80. 
Maka dapat dipahami 'urf adalah sesuatu yang telah biasa berlaku, diterima akal manusia dan dianggap baik oleh masyarakat. ${ }^{26}$ Sehingga 'urf dapat dapat dipahami dengan sesuatu yang baik dan menjadi kebiasaan masyarakat. Sedangkan 'adah adalah sesuatu perkataan atau perbuatan yang terus menerus dilakukan oleh masyarakat dan dapat diterima oleh akal dan manusia serta dilakukan secara berulang-ulang. ${ }^{27}$ Pada dasarnya kedua kata tersebut tidak memiliki perbedaan yang mencolok bahkan keduanya memiliki pengertian yang serupa yaitu sesuatu perkataan atau perbuatan yang dilakukan berulang-ulang dan disepakati oleh suatu komunitas tertentu secara umum.

Hal tersebut sesuai dengan pendapat sebagian besar ulama yang menyatakan bahwa, 'adah dan 'urf secara terminologis tidak memiliki perbedaan prinsipil. Misalnya dalam kitab fiqh terdapat ungkapan yang artinya, ketentuan ini berlandaskan 'urf dan 'adah, maka makna yang dimaksud keduanya adalah sama. Penyebutan 'adah setelah kata 'urf berfungsi sebagai penguat saja, bukan kalimat tersendiri yang mengandung makna berbeda. ${ }^{28}$

Adapun perbedaan, antara 'adah dan'urf adalah sebagai berikut, 'adah lebih luas cangkupannya bila dibandingkan dengan 'urf, 'urf terdiri dari 'urf sahih dan 'urf fasid sedangkan 'adah tanpa melihat apakah baik atau buruk, 'urf merupakan kebiasaan orang banyak sedangkan 'adah mencakup kebiasaan pribadi. persamaannya, antara 'adah dan'urf adalah

26 Lahmuddin Nasution, Pembaharuan Hukum Islam Dalam Mazhab Syafi'i (Bandung: PT Remaja Rosdakarya, 2001), 150.

27 Toha Andiko, Ilmu Qowa'id Fiqhiyyah Panduan Praktis dalam Memproses Problematika Hukum Islam Kontemporer, 139.

28 Rijal Mumazziq Zionis," Posisi al-'urf dalam Struktur Bangunan Hukum Islam", 132. 
sebuah pekerjaan yang sudah diterima akal sehat, tertanam dalam hati, dilakukan berulang-ulang, dan sesuai dengan karakter pelakunya. ${ }^{29}$

Maka, dapat disimpulkan bahwa istilah 'adah dan 'urf memang berbeda jika ditinjau dari dua aspek yang berbeda pula. Perbedaannya, istilah 'adah hanya menekankan pada aspek pengulangan pekerjaan. Sementara 'urf hanya melihat pelakunya. Di samping itu, 'adah bisa dilakukan oleh pribadi maupun kelompok, sementara 'urf harus harus dijalani oleh komunitas tertentu. Sederhananya, 'adah hanya melihat aspek pekerjaan, sedangkan 'urf lebih menekankan aspek pelakunya.

\section{'URF DALAM DIMENSI SEJARAH}

Secara historis, ketika Rasulullah hadir, sebagai legislator Islam di wilayah Makkah maupun Madinah, beliau banyak mengadopsi 'urf setempat. Sebagian 'urf tersebut ditetapkan oleh wahyu al-Qur'an dan alHadith. Meskipun demikian, tidak semua 'urf masyarakat Arab sebelum Islam dijadikan sebagai ajaran Islam. Tradisi yang ditetapkan dalam alQur'an dan al-Hadith diantaranya adalah sebagai berikut, ibadah haji, puasa, kewarisan, bentuk-bentuk perdagangan, khitanan dan qurban. Namun demikian tidak semua tradisi Arab atau non Arab itu diadopsi menjadi bagian dari shari'ah Islam, beberapa di antaranya direvisi, dimodifikasi. Dan sebagian yang lainnya dibatalkan berdasarkan wahyu dari Allah seperti persoalan riba dan cara memperlakukan kaum perempuan. ${ }^{30}$

Fakta diatas menunjukkan bahwa perkembangan Hukum Islam (syariah maupun fiqh) senantiasa berbasis pada 'urf. Proses perkembangan Hukum Islam tersebut senatiasa melibatkan dialektika budaya yang terus menerus, sehingga menghasilkan fiqh. bahkan sebabsebab lahirnya isi al-Qur'an dan al-Hadith selau berkaitan dengan ruang, 
rentetan waktu dan peristiwa. Semua terjadi sebagai respon terhadap persoalan-persoalan yang berkembang pasa masa itu.

Para sahabat sepeninggal rasulullah tidak menutup diri untuk mengambil tradisi dan sistem masyarakat lain selama tidak bertentangan dengan al-Qur'an dan al-Hadith. Fungsi al-Qur'an dan alHadith, dalam hal ini, selain sebagai sumber inspirasi penggalian hukum juga menjadi petunjuk pelaksanaan pembentukan Hukum Islam. Khalifahan Umar bin Khattab mengadopsi sistem dan kelembagaan dalam kekhalifahannya sesuai dengan model yang pernah diterapkan oleh penguasa Bizantium . pada masa Rasulullah dan masa sahabat 'urf dianggap sebagai salah satu sumber dan landasan dalam pembangunan Hukum Islam. Di kalangan para ulama fiqh, Imam Malik dalam memutuskan persoalan fiqhiyah senantiasa menyandarkan pada 'urf yang dilakukan oleh masyarakat Madinah. Sikap yang sama dilakukan oleh Imam Shafi'i ketika berada di Mesir dan di Baghdad. Karena 'urf di Mesir dan di Baghdad berlainan, maka Imam Shafi'i pun merubah qawl al-qadim menjadi qawl al-jadid. ${ }^{31}$ Hal ini menunjukkan bahwa, para ulama dalam menentukan hukum senantiasa menggunakan 'urf sebagai acuan.

\section{PERKEMBANGAN 'URF DALAM MASYARAKAT}

Telah kita ketahui bersama bahwa perkembangan suatu masyarakat membawa dampak kepada perubahan dan perkembangan 'urf atau adah masyarakat yang bersangkutan. Menurut Ibnu Khaldun, "hiruk-pikuk umat manusia, adat kebiasaan dan peradabannya tidaklah pada suatu gerak dari garis yang tetap, melainkan berubah-ubah dan berbeda-beda, sebagaimana manusia, waktu, tempat, dunia dan Negara

31 Zionis, 139. 
juga selalu mengalami perubahan. Sesungguhnya sunnatullah berlaku bagi hamba-hambaNya".

Contoh; Pada masa Islam, para guru pengajar al-Qur'an menerima hadiah dari masyarakat yang besarnya cukup lumayan, lalu Abu Hanifah dan kedua muridnya (Muhammad dan Yusuf) tidak membolehkan para guru Al-Qur'an tersebut memungut upah. Akan tetapi setelah keadaan berubah dimana para guru sudah tidak dapat lagi menerima hadiah atas amalnya, maka para Ulma' muta'akhirin bersepakat untuk memberikan fatwa yang membolehkan pemberian upah atas pekerjaannya tersebut karena berubahan adat. Tata cara berpakaian dan cara makan masyarakat dunia ketiga, dulu makan dengan sendok dan garbu atau berpakaian jas lengkap dengan dasinya bisa dianggap tashabuh dengan orang kafir, sehingga hukumanya haram tetapi sekarang tidak. ${ }^{32}$

Perlu diketahui bahwa sebagian 'urf atau tradisi yang ditetapkan dalam al-Qur'an dan al-Hadit diantaranya adalah sebagai berikut, ibadah haji, puasa, kewarisan, bentuk-bentuk perdagangan, khitanan dan qurban. Namun demikian tidak semua tradisi masyarakat diadopsi menjadi bagian dari shari'ah Islam, beberapa di antaranya direvisi, dimodifikasi dan sebagian yang lainnya dibatalkan berdasarkan wahyu dari Allah seperti persoalan riba dan cara memperlakukan kaum perempuan seperti memperlakukan barang yang bisa diperjual belikan dan diwariskan. Mereka tidak mempunyai hak apapun terhadap diri mereka sendiri. ${ }^{33}$ Banyak sekali masalah hukum yang ditetapkan berdasarkan 'urf. Contohnya dalam kajian fiqh, banyak sekali masalah

32 Muhammad Ma'sum Zainy al-Hasyimy, Sistematika Teori Hukum Islam (Qowa'id Fiqhiyyah) , 84.

33 Rijal Mumazziq Zionis,"Posisi al-'Urf dalam Struktur Bangunan Hukum Islam”, 137. 
yang ditetapkan berdasarkan 'urf. Misalnya masalah masa baligh, haid, nifas dan suci, najis yang dimaafkan kerana sedikit dan lain sebagainya. ${ }^{34}$

\section{'URF SEBAGAI METODE DAN SUMBER HUKUM EKONOMI ISLAM}

Ekonomi syariah merupakan ilmu pengetahuan sosial yang mempelajari masalah-masalah ekonomi rakyat yang dilhami oleh nilainilai Islam. Ekonomi syariah atau sistem ekonomi koperasi berbeda dari kapitalisme, sosialisme, maupun negara kesejahteraan (welfare state). Berbeda dari sistem kapitalisme, sistem Ekonomi Islam menentang eksploitasi oleh pemilik modal terhadap buruh yang miskin, dan melarang penumpukan kekayaan. Selain itu, ekonomi dalam kacamata Islam merupakan tuntutan kehidupan sekaligus anjuran yang memiliki dimensi ibadah yang teraplikasi dalam etika dan moral syariah Islam. ${ }^{35}$

Sistem ekonomi syariah sangat berbeda dengan ekonomi kapitalis, sosialis maupun komunis. Ekonomi syariah bukan pula berada di tengah-tengah ketiga sistem ekonomi itu. Sangat bertolak belakang dengan kapitalis yang lebih bersifat individual, sosialis yang memberikan hampir semua tanggung jawab kepada warganya serta komunis yang ekstrem, ekonomi Islam menetapkan bentuk perdagangan serta perkhidmatan yang boleh dan tidak boleh di transaksikan. Ekonomi dalam Islam harus mampu memberikan kesejahteraan bagi seluruh masyarakat, memberikan rasa adil, kebersamaan dan kekeluargaan serta mampu memberikan kesempatan seluas-luasnya kepada setiap pelaku usaha. ${ }^{36}$

\footnotetext{
34 Mohd Anuar Ramli, "Instrumen'Urf dan Adat Melayu Sebagai Asas Penetapan Hukum Semasa di Malaysia”, 257.

35 Veitzal Rivai, "Keistimewaan Ekonomi Islam dalam Mempercepat Pertumbuhan Ekonomi Umat," Journal Analytica Islamica, Vol 1 no 2, (2012), 344-352.

36 Taqiyuddin An-Nabhani, Sistem Ekonomi Islam, terj. Muhadi Zainuddin (Yogyakarta: UII Pres, 2000), 12-63.
} 
Sebagaimana diungkapkan dalam pembahasan diatas, ekonomi Islam harus mampu memberikan kesempatan seluas-luasnya kepada setiap pelaku usaha. Selain itu, ekonomi syariah menekankan empat sifat, antara lain: Kesatuan (unity), Keseimbangan (equilibrium), Kebebasan (free will), Tanggung jawab (responsibility). Manusia sebagai wakil (khalifah) Tuhan di dunia tidak mungkin bersifat individualistik, karena semua (kekayaan) yang ada di bumi adalah milik Allah semata, dan manusia adalah kepercayaan-Nya di bumi. Di dalam menjalankan kegiatan ekonominya, Islam sangat mengharamkan kegiatan riba seperti yang dijelaskan dalam al-Qur'an surat al-Baqarah ayat 275. Ekonomi Islam mempunyai tujuan untuk memberikan keselarasan bagi kehidupan di dunia dan akhirat. Nilai Islam bukan semata-semata hanya untuk kehidupan muslim saja, tetapi seluruh mahluk hidup di muka bumi. Esensi proses Ekonomi Islam adalah pemenuhan kebutuhan manusia yang berlandaskan nilai-nilai Islam guna mencapai kesejahteraan (falah).

Sedangkan keterkairan antara hukum dan kegiatan ekonomi tercermin dari terjadinya akad. Akad adalah proses yang penting di dalam proses kegiatan ekonomi, tanpa adanya akad proses trransaksi menjadi tidak sah, karena tidak adanya perjanjian di awal oleh kedua belah pihak. Proses kepemilikin adalah bentuk proses perpindahan hak milik berdasarkan transaksi, setelah terjadinya kesepakatan antara kedua belah pihak, untuk memindahkan hak milik kepada pihak kedua melalui pihak pertama, misalnya dalam transaksi jual beli, sewamenyewa dan lain sebagainya. Dalam hal tersebut selalu ada keterkaitan antara aspek hukum dan ekonomi Islam. Sehingga kegiatan dalam ekonomi Islam digali dari hukum Islam itu sendiri, di dalam Islam kegiatan ekonomi dan hukum tidak dapat dipisahkan.

Sumber utama dalam hukum Islam adalah al-Qur'an, didalamnya menegaskan bahwa Nabi Muhammad diberi kewenangan untuk 
menjelaskan hukum-hukum yang ada dalam al-Qur'an dan dalam beberapa hal memberikan ketentuan hukum baru. Dengan demikian, Sunnah Rasul merupakan sumber kedua hukum Islam setelah al-Qur'an. Sunnah Rasul memberikan kesempatan kepada umat Islam untuk menemukan ketentuan-ketentuan hukum yang tidak disebutkan dalam al-Qur'an atau Sunnah Rasul secara jelas dengan jalan ijtihad. Dengan demikian, ijtihad dapat dipandang sebagai sumber ketiga hukum Islam.

Hukum-hukum ijtihadiyah pada pokoknya bersumber kepada qiyas dan pertimbangan kepentingan dan kemaslahatan masyarakat. Di antata yang akan mendatangkan kebaikan dan memnuhi kepentingan masyarakat adalah mengukuhkan berlakunya 'urf yang tidak bertentangan dengan nash al-Quran dan Sunnah Rasul.

\section{PENERAPAN 'URF DALAM TRANSAKSI KEGIATAN EKONOMI}

Kajian di atas mempertegas bahwa setiap aktivitas ekonomi Islam haruslah selalu berlandaskan kepada sumber-sumber hukum ekonomi Islam. Artinya dalam berijtihad terhadap suatu fenomena perekonomian tidak boleh bertentangan dengan prinsip-prinsip ekonomi Islam. Prinsip-prinsip ini harus dijadikan sebagai aturan dalam melakukan aktivitas ekonomi.

Karakteristik hukum Islam adalah syumul (universal) dan waqiyah (kontekstual) karena dalam sejarah perkembangan (penetapan)nya sangat memperhatikan tradisi, kondisi (sosiokultural), dan tempat masyarakat sebagai objek, dan sekaligus subjek (pelaku, pelaksana) hukum. Perjalanan selanjutnya, para Imam Mujtahid dalam menerapkan atau menetapkan suatu ketentuan hukum (fiqh) juga tidak mengesampingkan perhatiannya terhadap tradisi, kondisi, dan kultural setempat ('urf). 
'Urf telah terbukti dapat dijadikan sebagai dasar untuk mencari titik temu antara aktivitas ekonomi yang berkembang di masyarakat dengan praktek ekonomi yang bersendikan Islam. 'Urf shahih terbukti mempunyai titik temu yang sangat jelas, karena 'urf merupakan segala sesuatu yang sudah saling dikenal di antara manusia yang telah menjadi kebiasaan atau tradisi, baik bersifat perkataan, perbuatan atau dalam kaitannya dengan meninggalkan perbuatan tertentu. Dengan demikian 'urf untuk selanjutnya dapat dijadikan sebagai metode dan sumber hukum Islam (justifikasi) dalam perkembangan perekonomian karena sesuai dengan hukum dan prinsip-prinsip ekonomi Islam. ${ }^{37}$

Dari penjelasan diiatas dapat disimpulkan bahwa 'urf dapat dapat dijadikan landasan hukum untuk melakukan transaksi ekonomi. Karena perkembangan industri yang semakin maju akan berdampak pada perkembangan transaksi dalam ekonomi yang semakin komplek sehingga banyak kegiatan transaksi yang membutuhkan ijtihad untuk mencari solusinya dari permasalan yang mungkin muncul. Adapun yang dimaksud ekonomi Islam adalah sebuah usaha sistematis untuk memahami masalah-masalah ekonomi dan tingkah laku manusia secara relasional dalam perspektif Islam. ${ }^{38 J a d i}$ dapat difahami ekonomi Islam merupakan ilmu yang mempelajari perilaku muslim dalam kegiatankegiatan ekonomi seperti produksi, distribusi, konsumsi dan investasi sehingga tercipta suatu perekonomian yang teratur, terarah sesuai dengan tujuannya berdasarkan ajaran Islam.

Contoh 'urf dalam ekonomi Islam adalah jual beli yang dilakukan masyarkat tanpa mengucapkan shighat ijab (misal; saya jual-saya beli). Di supermarket atau pusat perbelanjaan lainya pembeli tinggal mengambil barang yang diinginkan sendiri kemudian langsung

37 Abdul Hakim, "Kearifan Lokal dalam Ekonomi Islam (Studi Atas Aplikasi alUrf Sebagai Dasar Adopsi)”, Jurnal Akademika, Vol. 8, No. 1, (Juni 2014).

38 Veithzal Rivai dan Arviyan Arifin, Islamic Banking (Jakarta: PT. Bumi Aksara, 2010), 235. 
membayar dikasir. Apalagi uang sebagai alat pembayaran transaksi juga sudah nontunai, cukup menggunakan uang elektronik, kartu ATM atau lainnya. Kemudian diberbagai sektor pola konsumsi masyarakakat hari ini lebih ke nontunai dan online disegala aspek ekonomi, dari jalan tol, gaji bulanan, bayar listrik, jasa ojek, pesan makan, pesan tiket dan hotel, beli perabotan rumah tangga, buku dan lain sebagainya. Hari ini masyarakat dimudahkan dengan hanya membuka aplikasi kemudian memencet tombol-tombol dan akhirnya transaksi berhasil.

Dalam fiqh muamalah semestinya shighat merupakan hal yang menjadi rukun jual beli yang harus dipenuhi. Namun secara substantif, shighat itu adalah untuk menunjukkan adanya ridha (kerelaan) dari kedua belah pihak sebagaimana yang difirmankan Allah Swt yang artinya "Hai orang-orang yang beriman, janganlah kamu saling memakan harta sesamamu dengan jalan yang batil, kecuali dengan jalan perniagaan yang berlaku dengan suka sama-suka di antara kamu (Q.S.AN-Nisa': 29). Nabi Muhammad Saw juga bersabda "Sesungguhnya jual-beli itu haruslah dengan saling rela/ridha"(HR. Ibn Majah)".

Dari penjelasan diatas dapat dipahami bahwa setiap transaksi jual beli harus dilakukan dengan kerelaan oleh kedua belah pihak. Pada mulanya, shighat haruslah berupa ucapan (saya jual) dari penjual dan ucapan pembeli (saya beli). Namun kebiasaan kegiatan transaksi ekonomi modern hari ini ('urf) merubah segalanya menjadi lebih mudah. Misal shighat menjual diwakili dengan label harga (online atau offline) pada produk yang diinginkan dan shighat membeli diwakili dengan kesediaan memberi uang (tunai atau non tunai) ataupun dengan hanya gerakan jari (pencet tombol "ok") di Hp atau yang sejenisnya. Walaupun tidak seperti shighat yang dijelaskan di literature klasik, namun karena mengandung arti yang menunjukkan kerelaan dari kedua belah pihak 
maka dapat disimpulkan bahwa hukum transaksi modern tersebut boleh berdasarkan 'urf.

\section{KESIMPULAN}

'Urf merupakan suatu hal yang dikenal dan sudah menjadi kebiasaan masyarkat, baik berupa ucapan ataupun perbuatan. 'Urf terbagi menjadi dua, yaitu 'urf shahih dan 'urf fasid. 'Urf shahih merupakan kebiasaan masyarakat yang tidak bertentangan dengan ajaran Islam, sedangkan 'urf fasid adalah kebiasaan masyarakat yang bertentangan dengan ajaran Islam. Hanya 'urf shahih yang bisa dijadikan sebagai landasan sumber hukum Islam. Jadi dapat disimpulkan 'urf dapat dijadikan landasan hukum untuk melakukan transaksi ekonomi. Karena perkembangan industri yang semakin maju akan berdampak pada perkembangan transaksi dalam ekonomi yang semakin komplek sehingga banyak kegiatan transaksi yang membutuhkan ijtihad untuk mencari solusinya dari permasalan yang mungkin muncul.

Contoh penerapan 'urf dalam transaksi ekonomi Islam haru ini adalah seperti dalam jual beli yang dilakukan masyarkat tanpa mengucapkan shighat ijab qabul (saya jual-saya beli). Di supermarket atau pusat perbelanjaan modern pembeli tinggal mengambil barang yang diinginkan sendiri kemudian langsung membayar dikasir. Apalagi uang yang digunakan sebagai alat pembayaran transaksi juga sudah nontunai. Dan masih banyak lagi kegiatan trasaksi ekonomi modern saat ini yang berbasis elektronik dan internet. Walaupun tidak seperti shighat yang dijelaskan di literature klasik, namun karena mengandung arti yang menunjukkan kerelaan dari kedua belah pihak maka dapat disimpulkan bahwa hukum transaksi modern tersebut boleh berdasarkan 'urf. 


\section{DAFTAR PUSTAKA}

Abdullah, Ahmad Sufyan Che. "Aplikasi Doktrin al-'Urf dalam Istrumen Pasaran Kewangan Islam di Malaysia", Universitas Malaya Kuala Lumpur, (2002).

Abdullah, Sulaiman. Sumber Hukum Islam Permasalahan dan Fleksibilitinya. Jakarta: Sinar Grafika, 2007.

Al-Hasyimy, Muhammad Ma'sum Zainy. Pengantar Memahami Nadhom Al-Faroidul Bahiyyah. Jombang: Darul Hikmah Jombang, 2010.

Al-Hasyimy, Muhammad ma'sum Zainy. Sistematika Teori Hukum Islam (Qowa'id Fiqhiyyah). Jombang: Darul Hikmah Jombang dan Maktabah Al-Syarifah Al-Khodijah, 2008.

Andiko, Toha. Ilmu Qowa'id Fiqhiyyah Panduan Praktis dalam Memproses Problematika Hukum Islam Kontemporer. Yogyakarta: Teras, 2011.

An-Nabhani, Taqiyuddin. Sistem Ekonomi Islam, terj. Muhadi Zainuddin. Yogyakarta: UII Pres, 2000.

Djalil, Basiq. Ilmu Ushul Fiqh Satu dan Dua. Jakarta: Kencana Prenada Media Group, 2010

Hakim, Abdul. "Kearifan Lokal dalam Ekonomi Islam (Studi Atas Aplikasi al-Urf Sebagai Dasar Adopsi)”, Jurnal Akademika, Volume 8, Nomor 1, (Juni 2014).

Nasution, Lahmuddin. Pembaharuan Hukum Islam dalam Mazhab Syafi'i. Bandung: PT Remaja Rosdakarya, 2001.

Ramli, Mohd Anuar. "Instrumen 'Urf dan Adat Melayu Sebagai Asas Penetapan Hukum Semasa di Malaysia". Jurnal Pengajian Melayu, Jilid 17,( 2006).

Rivai, Veithzal dan Arifin, Arviyan. Islamic Banking. Jakarta: PT. Bumi Aksara, 2010.

Rivai, Veitzal. "Keistimewaan Ekonomi Islam dalam Mempercepat Pertumbuhan Ekonomi Umat," Journal Analytica Islamica vol 1 no 2, (2012).

Rosyadi, Imron. "Kedudukan al-'Adah wa al-'urf dalam Bangunan Hukum Islam". Jurnal Suhuf Vol. Xvii, No. 01, 2005.

Saleh, Abdul Mun'im. Hubungan kerja Usul al-Fiqh dan al-Qawaid alFiqhiyah Sebagai Metode Hukum Islam. Yogyakarta: Nadi Pustaka, 2012.

Syafe'i, Racmat. Ilmu Ushul Fiqh. Bandung: Pustaka Setia, 2010.

Syihab, Umar. Hukum Islam dan Trasformasi Pemikiran. Semarang: Dina Utama Semarang (Toha Putra Group), 1996.

Zionis, Rijal Mumazziq."Posisi al-'Urf dalam Struktur Bangunan Hukum Islam". Jurnal Falasifa, Vol. 2 No. 2, (2011). 